\title{
Recent Developments in Goat Farming and Perspectives for a Sustainable Production in Western Africa
}

\author{
Dehouegnon Jerry Agossou ${ }^{1}$, Tatiana Dominica Dougba ${ }^{2}$, Nazan Koluman ${ }^{1}$ \\ ${ }^{1}$ Department of Animal Science, Faculty of Agriculture, Çukurova University, 01330, Adana, Turkey \\ ${ }^{2}$ Departement of Animal Science, University of Legon, P.O Box LG 25, Accra Ghana
}

\begin{abstract}
The West African region has a great diversity of indigenous goat breeds that are well adapted to such environmental conditions. West African goat population was estimated to be around 150 million heads in 2014, representing $14.82 \%$ of the world goat population. Goats play an important role in the socio-economic, environmental and religious life of the farming communities in terms of income, payment of dowry and supplying food for the local population. The traditional keeping system based on natural rangeland use as feed resources and free roaming is the most common system in the regions. Although goat industries have significantly increased these last decades, they are subjected to a variety of factors limiting their development. For a sustainable development with the goals of meeting the increasing demand for goat products, a wide intensification of goat production policies should be implemented.
\end{abstract}

Keywords_Goat, Meat, Milk, Skin, West Africa.

\section{INTRODUCTION}

Livestock especially goat production is a traditional activity practiced by $60-87 \%$ of the local populations either as the main activity or as a secondary activity [1, 2]. Goats play an important socio economic role in many West African local populations. African goat population represents $30 \%$ of Africa's ruminant livestock and produce about 17 and $12 \%$ of its meat and milk, respectively. According to the data of Food and Agriculture Organization of United Nation in 2014, the West African population of goats was approximately 150 million heads accounting for $14.82 \%$ of goat population in the world. Nigeria (48.34\%), Mali (12.76\%), Niger $(9.93 \%)$ and Burkina Faso $(9.27 \%)$ host a large number of goats [3]. Although it's crucial importance, goats still remain largely marginalized, even at the household level [4]. Therefore, there is the need for the understanding of the role of goat, the diversity of production systems, and the current production of goat products, and constraints that will contribute to establishing strategies to advance the development of this sector.

\section{GOAT FARMING AND PRODUCTION IN WEST AFRICA}

West African area involves a wide range of indigenous goat breeds well adapted to harsh environmental and precarious husbandry conditions but have low genetic potentials. The geographical distribution of the different SRs breeds in West Africa is almost exclusively determined by the presence or absence of the tsetse fly in the region. The vast majority of sheep and goats in the areas of high tsetse challenge are the West African dwarf trypanotolerant breeds. In the savannah and the semi-arid zone, the larger sized, long-legged Sahelian breeds thrive well $[5 ; 6]$. West African Dwarf goat is small size animals with a low meat yield and very low lactogenic productive potential $[7,8]$.

The West African Sahelian goat is a long leg breed mainly raised mainly for meat, skin and milk production. The Sahelian is large, long-legged goats mainly found in the semi-arid and arid of the Saharan and sub-Saharan region in distribution. It is a very rustic and butcher animal. In Liberia, there are considerable numbers of the Red Sokoto breed and crosses between the WAD and the Red Sokoto goat breeds [9]. Red Sokoto is also known as Maradi goat is used for the good quality skin production in Nigeria and Niger.

Additionally, some exotic breed such as Alpine goat (in Benin), Anglo-Nubian, Toggenburg, Boer, Saanen (in Nigeria) and Majorera goat (in Senegal) have been imported in order to increase the profitability of goat farming $[8,10,11]$. These breeds are currently being kept under an acclimatization research program and in some commercial private farm. In 2014, West African meat produced from indigenous goat, milk and skin from goat was, respectively, $39.7 \%, 24.5 \%$ and $36.4 \%$ of the African production [3]. The main indigenous meat, milk and skin producer countries in the region are shown in Table. Thus, countries like Mali, Mauritania, Niger, and 
Burkina Faso produce over $95 \%$ of the whole fresh goat milk. Regarding indigenous meat, it is mainly produced in Nigeria $(55.53 \%)$, Mali $(14.85 \%)$, and Niger $(8.87 \%)$, with $79.25 \%$ of the regional production [3].

The most spread meat processing methods of goat is the slaughtering procedures of animals. Indeed, according to the size, conformation and breed, animals are sold transported and slaughtered. Then, the cuts of fresh meat are collected and sold by retailer butchers to consumers on the local markets. Additionally, the fresh meat is processed and sold as fried or grilled meat directly consumed. After slaughtering, the skin is tanned to leather which is used in the textile industry or to make shoes.

\section{GOATS FARMING SYSTEM}

Goats are mainly kept in the traditional system. The traditional system is made up pastoral systems and agropastoral systems. However, some semi-intensive systems, ranching, and intensive dairy farming are encountered. These production systems differ from place to place due to socio-economic reasons.

\subsection{Pastoral system}

The pastoral system is the main traditional ruminant production systems and the widespread all across the region. It is a grassland-based system in which livestock include cattle, sheep, goats, and dromedaries. Pastoral systems are mainly encountered in the arid and semi-arid regions characterized by rainfall less than $600 \mathrm{~mm}$ per annum and 90 days of plant-growing period [12]. This system includes the nomadic pastoralism and transhumant pastoralism. The nomadic pastoralism is a pure pastoral system, characterized by little or no agriculture and by high mobility of people and animals in search of grazing and water. As for transhumant pastoralism, it is based on more or less regular seasonal migrations from a permanent homestead [9].

\subsection{Agropastoral system:}

it is a system in which livestock production is associated with dryland or rainfed cropping and animals range over short distances [12]. Agropastoralists are sedentary but sometimes practice transhumance. During the cropping season, animals are grazed on fallow lands and areas of natural vegetation. In the dry season, they are brought back to cultivated areas where they graze in swamps, rice fields and various areas which they cannot graze during the wet season [9].

\subsection{Sedentary extensive system}

In this system, goats are kept in free-roaming flocks or herds in villages and their environs, scavenging for feed. They have no benefit of prophylactic or curative medicinal treatment. Owners provide little or no supplementary feed. Good flock management practices are not applied and poor housing is provided to animals. Additionally, farmers having a small number of animals, and limited access to land tethered (in the compound/pens) free-roaming animals during the cropping season so as to avoid crop damage. Sometimes, animals may be tethered in areas where forages are available for in situ grazing. Cut-and-carried forage and waste from kitchen and crop processing are supplied in some instances to the animals [13, 9]. This is characterized by the absence of production target, limited food resource, low productivity and high losses due to accidents, diseases, and theft.

\subsection{Semi-intensive and intensive systems}

these systems are mainly encountered in urban and periurban areas where intensification of dairy production and small ruminants fattening are developed. Indeed, the increased demands for dairy products and meat of urban population led a gradual shift from extensive and unproductive livestock systems to more semi-intensive or intensive systems. Improved management practices such good housing of animals, supplementation of concentrate, appropriate breeding program, selection of best reproductive animals, and health monitoring of animals are applied.

Table.1: Goat population in West Africa

\begin{tabular}{|c|c|c|c|c|c|c|c|c|}
\hline Country & $\begin{array}{c}\text { Number } \\
\text { (1000 } \\
\text { Heads) }\end{array}$ & $\%$ & $\begin{array}{l}\text { Meat } \\
\text { (Tons) }\end{array}$ & $\%$ & $\begin{array}{c}\text { Milk } \\
\text { (Tons) }\end{array}$ & $\%$ & $\begin{array}{l}\text { Skin } \\
\text { (Tons) }\end{array}$ & $\%$ \\
\hline Nigeria & 72466.7 & 48.34 & 292650 & 55.53 & - & - & 46600 & 52.26 \\
\hline Mali & 19126.8 & 12.76 & 78260 & 14.85 & 420102 & 41.02 & 11120 & 12.47 \\
\hline Niger & 14883.6 & 9.93 & 46767 & 8.87 & 308099 & 30.08 & 8840 & 9.91 \\
\hline Burkina Faso & 13891 & 9.27 & 26468 & 5.02 & 116086 & 11.33 & 6947 & 7.79 \\
\hline Mauritania & 7040 & 4.70 & 18450 & 3.50 & 130975 & 12.79 & 1980 & 2.22 \\
\hline Ghana & 6044 & 4.03 & 21469 & 4.07 & - & - & 4248 & 4.76 \\
\hline Senegal & 5381.3 & 3.59 & 12937 & 2.45 & 13675 & 1.34 & 3905 & 4.38 \\
\hline
\end{tabular}

[3] FAOSTAT, 2017. 


\section{FACTORS LIMITING GOAT PRODUCTION IN WEST AFRICA}

\subsection{Goat keeping and environmental issues}

Climate change as a result of increased ambient temperature and concurrent changes in heat exchanges directly causes heat stress which influences growth, reproduction performance, milk production, wool production, animal health and welfare [14]. Heat stress caused by high temperature is a major constraint on animal productivity in the tropical belt and arid areas [15]. Research in West African Goat showed that the elevated temperature disturbs adversely the sexual activity, endocrine and testis functions, spermatogenesis and physical and chemical characteristics of buck semen [16]. Moreover, heat stress causes significant changes on behavioral, physiological and blood parameters via a reducing of feed intake, increasing of water consumption leading to weight loss $[17,18,19,20]$. Also, the depression of feed intake and reduction of milk production are commonly observed in heat-stressed goats [21].

On other hands, drought is particularly detrimental to agriculture in sub-Saharan Africa, where it causes about 90 percent of the sector's production losses, which contributes on average to one-quarter of GDP, or even half, including agri-food [22]. Drought and shortage of rainy season as result of changes in climate and extreme weather conditions affect the quality and availability of feed resources notably pasture and of drinking water. The countries which are generally affected by these long droughts are generally the countries of the Sahel and the Sahara (Mali, Burkina Faso) [23].

\subsection{Nutritional constraints}

In West African goat management system, grazing and browsing on natural pastures, feeding with crop residues, agro-industrial by-product, and kitchen wastes are the main feed sources for animals. In most part of the region goat freely roam about scavenging for food over the day. This feeding system exposes animals to diseases risks, especially those related to feeding and nutritional disorders. Additionally, the inadequate feed supplying, the poor quality (inadequate levels of crude protein) of the available feed resources and inefficiency use of the available feed resources are the main nutritional problems in goat farming. The seasonal variation of fodder in term of nutritional value and quantity is most of the year due to the rainfall pattern. This is aggravated by inadequate management of feed resources such as overgrazing in the arid and semi-arid zones where rainfall is less than 600 $\mathrm{mm}$ and between $600-1000 \mathrm{~mm}$ per year, respectively [24].

\subsection{Management and Diseases}

www.ijeab.com
The mismanagement and high prevalence of diseases and parasites are one of most limiting factors in the development of goat farming in West Africa. Diseases cause important direct and indirect losses of the high reproductive performance diminishing of benefits for farmers. The dominant pathologies within the goat population can be grouped into two categories: parasitic diseases and infectious diseases. Although some efforts have been made to eradicate PPR (Peste des Petit Ruminants) is still one of the main diseases affecting West African goat flocks. Due to the high mortalities rate for which they are responsible, pneumopathies and internal parasitoses (intestinal worms) are undoubtedly ones of the major constraints of goat farming in West Africa.

\subsection{Difficulty in access to loans}

For processing, farmers need to invest. Due to lack sufficient own resources, difficulties to access financial services (credit, savings, insurance), they are limited to primary production. These financial services and the supply of credit especially, remain failing in response to demand from farms. And then, farmers and agricultural organizations are particularly disadvantaged in access to credit [25].

\section{STRATEGIES FOR A SUSTAINABLE DEVELOPMENT OF GOAT FARMING}

In order to meet the increasing demand for livestock products especially goat, livestock development policies and strategies with an emphasis on the intensification of production methods and diseases control the introduction of exotic breeds to increase livestock production capacities.

\subsection{Improving the productivity of native breeds}

Genetic improvement through the selection or crossbreeding is very important to improve the genetic potential and livestock productivity. Thus, an effective breeding program including researchers, farmers and governmental institutions should be implemented to increase the meat, skin and milk yield of the indigenous goat by adopting within breed selection programs or controlled cross-breeding using exogenous breeds with high productivity.

5.2. Governmental policies for supporting the goat sector

The government through Ministries must have adequate resources, well-trained working staff to carry out activities and a modern and efficient internal functioning. It should support farmers by subsiding inputs costs (feed, drugs, fuel, machinery etc) and be regulating the animal products (milk, meat, and skin) prices on the markets. It also facilitates the access of farmers to credit services, the good animal reproducers. An effective animal health 
inspection service should be implemented. In addition, regular extension service and veterinary services should be provided to famers. The implementation of modern slaughterhouses and subsidies for processing of animals should be considered in order to add value to the animal's products and improve livelihood of farmers.

\subsection{Research and training}

The goal of intensification and valorization of animal production can only be achieved with actors whose skills should be adapted to new production technologies. Governments should grant research and redirect its priorities to innovative action to enhance food selfsufficiency and reduction of poverty notably in the rural area. In order to be competitive and safety in term of biosecurity in future, the breeding must acquire appropriate skills and be able to adapt to changes. The Periodic training session should be set up to strengthen the research-extension link, the capacity and knowledge of breeders to improve the keeping and management practices of their business. Association of breeders and inputs and services suppliers involved in livestock value chains should be reorganized to defend the common interests and to adopt facilitation practices to be more competitive on markets.

\section{CONCLUSION}

The main products from goat production in West Africa are meat, milk, and skin. Although many project and governmental actions have been taken to increase production of goat, it is still undeveloped. Constraints related feeding, health, management of flock, lack of structural and institutional organization are the major limiting the increase of the subsector. Therefore, strategic plan to increase animal productivity, the income of producers and the preservation of environment needs to be implemented. It should ensure the improvement of feeding, health care, the introduction of modern reproductive methods and management practices. Governments should also a) promote the access of farmers to the credit services, b) strengthen rural infrastructure through the rehabilitation or construction of pastoral hydraulic infrastructures, rural roads, slaughterhouses, meat, and milk processing industries and c) ensure sustainable management of natural resources through the regulation of their overusing by pastoralist.

\section{REFERENCES}

[1] Institut Senegalais de Recherches Agricoles. Rapport National sur L'état des Ressources Zoogenetiques au Senegal. Avril 2003.

[2] Ministère de L'Elevage. Stratégie de Développement Durable de L'Elevage (SDDEL 2013-2035), République du Niger. Mai 2013.
[3] FAOSTAT http://www.fao.org/faostat/en/\#data/QA Accessed on 8 July 2017.

[4] S.H.B. Lebbie (2004), Goats under Household Conditions. Small Ruminant Res., 51: 131-136, 2004.

[5] V. M. Timon, R.P. Baber. Genetic improvement of sheep and goats in the humid tropics of West Africa (English). In: Sheep and goat meat production in the humid tropics of West Africa. Proceedings ; FAO Animal Production and Health Paper (FAO), no. 70; Seminar on Sheep and Goat Meat Production in the Humid Tropics of West Africa, Yamoussoukro (Cote d'Ivoire), 21-25 Sep 1987 / FAO, Rome (Italy). Animal Production and Health Div. p. 14-29, 1989,

[6] B.A. Opasina, K.B. David-West, Position paper on Sheep and Goats production in Nigeria. Sheep and Goat meat production in the humid of West Africa, 2007.

[7] A.B. Gbangboché, F.A. Abiola, J.P. Laporte, S. Salifou, P.L. Leroy, Sheep Management in Oueme and Plateau Departments of Republic of Benin. Stakes of Djallonke Crossbreeding with Sahelian Sheep. Tropicultura 20 (2): 70-75, 2002.

[8] R.K.E. Monkotan, Evaluation des performances laitières des chèvres alpines de la ferme SaintPhilippe de la providence de Têlokoue dans le département de l'atlantique. Mémoire pour l'obtention du diplôme d'ingénieur des travaux agricoles, Université d'Abomey-Calavi, 2011.

[9] L. Asamoah, Country Pasture/Forage Resource Profiles, Liberia. FAO, Rome 2012.

[10] J. Capote, Environments and goats around the world: importance of genetic and management factors. In: Kukovics S (ed) Sustainable Goat Breeding and Goat Farming in Central and Eastern, European Countries European regional conference on Goats. FAO, Rome, 2016, pp 1-16. ISBN: 978-92-5-109123-4, 2014.

[11]D. Vissoh, A.B. Gbangboche, E. Padonou, The alpine goat's milk production and cheese yield in Benin. International Journal of Current Research 7: 2210822112, 2015.

[12]M. J. Otte, P. Chilonda, Cattle and small ruminant production systems in sub-Saharan Africa: A systematic review. Food and Agriculture Organization of the United Nations Rome 2002.

[13]E. O. Otchere, Small Ruminant Production in Tropical Africa. In: Timon VM and Hanrahan JP, Small ruminant production in the developing countries, Proceedings of an Expert Consultation, Sofia, Bulgaria, 8-12 July 1985. Food and Agriculture Organization of the United Nations Rome, 1986.

[14]E. G. Kimaro, O.C. Chibinga, Potential impact of climate change on livestock production and health in 
East Africa: A review. Livestock Research for Rural Development. Volume 25, Article \#116. from http://www.lrrd.org/lrrd25/7/kima25116.htm Retrieved July 10, 2017,

[15]N. Silanikove, Effects of water scarcity and hot environment on appetite and digestion in ruminants: A review. Livestock Production Science. 30: 175194, 1992.

[16] J. O. Daramola, A.A. Adeloye, Changes in spermiograms, biochemical and physiological indices following successive electroejaculation during different periods of the day in West African dwarf bucks. Journal of Agriculture and Environmental Sciences 10; 53-60, 2010.

[17]T. A. Adedeji, Effect of Some Qualitative Traits and Non-Genetic Factors on Heat Tolerance Attributes of Extensively Reared West African Dwarf (WAD) Goats. International Journal of Applied Agricultural and Apicultural Research 8 (1): 68-81, 2012.

[18] M .A. Popoola, M.O. Bolarinwa M.O. Yahaya, G.L. Adebisi A.A. Saka, Thermal Comfort Effects on Physiological Adaptations and Growth Performance of West African Dwarf Goats Raised in Nigeria. European Scientific Journal February vol .3 (Special edition) ISSN: 1857-7881, 2014.

[19] M.I. Okourwa, Effect of Coat Characteristics on Physiological Traits and Heat Tolerance of West African Dwarf Sheep in Southern Nigeria. Open Journal of Animal Sciences 5: 351-357, 2015.

[20]M.I. Okoruwa, Effect of Heat Stress on Thermoregulatory, Live Bodyweight and Physiological Responses of Dwarf Goats in Southern Nigeria. European Scientific Journal September 2014 edition vol.10, $\mathrm{N}^{\circ} .27$ ISSN: 1857-7881, 2014.

[21] A. Rosa, A. di Palucci,, A. Zumbo, Climatic effect on milk production of Camosciata goats reared in Calabria. Large Animal Review 19 (2): 73-78, 2013.

[22]FAO Corporate Document Repository. hppt://wwwfao.org/dorep/004/s8374 s8374b20.htm.

[23] T. Metahan, La croissance de la population et le problème alimentaire en Afrique. Mémoire de DESS, Université de Columbia de New York. 2010 http://www.memoireonline.com/08/11/4670/Lacroiss ance-de-la-population-et-le-probleme-alimentaire-enAfrique.html

[24] A.A. Ademosun, Constraints and prospects for small ruminant research and development in Africa. In Lebbie S.H.B., B. Rey, E.K. Irungu (eds). Proceedings of the Second Biennial Conference of the African Small Ruminant Research Network AICC, Arusha, Tanzania 7-11 December 1992.
[25]Anon, [online] Available at: https://www.inter reseaux.org/IMG/pdf/gds72_complet.pdf Accessed on 19 July 2017. 